\title{
Analyses of Rainfall Rate During Malaysian 2014 Flood Event
}

Atikah Balqis Basri, Ahmad Fadzil Ismail, Muhamad Haziq Khairolanuar, Nuurul Hudaa Mohd Sobli, Khairayu Badron and Mohammad Kamrul Hasan

1Department of Electrical and Computer Engineering, Kulliyyah of Engineering, International Islamic University Malaysia (IIUM),

Jln. Gombak, Selangor, Malaysia.

Email: atikahbalqis32@gmail.com,af_ismail@iium.edu.my,haziq@iium.edu.my, hudaa@iium.edu.my,khairayu@iium.edu.my, and hasankamrul@ieee.org •

\begin{abstract}
An analysis based on rainfall rate characteristics has been carried out to estimate flood occurance. In this paper, we analyzed the rain gauge data for 5 different rain gauge stations. 14 days acquired data covering events before during and after the flood tragedy in Malaysia. The analysis of the rain gauge daty was processed on precipitation phenomena observed in year 2014 in Kota Bharu, Ketantan (Malaysia) from 13 December until 26 December. The data was acquired from the Malaysian Drainage and Irrigation Department (DID). The objective of the research to derive the tropical flood estimation model using rain gauge data in Malaysia. Among the preliminary result shows that the average rainfall rate at kota kharu is 204.5 mm/ hr during the flood tragedy.
\end{abstract}

Keywords: Rainfall Rate, Flood Model, Flood Estimation Model

\section{Introduction}

Flood refers to disastens that are among the world's most frequent and destructive types of disaster [1]. Flood hazard is ond of the calamities that commonly occur in Malaysia almost every year. During the end of year 2014, Malaysia experienced devastating flood hazards during the month of December in several states including Kelantan, Terengganu, Pahang, Perak, Johor, Perlis, Sabah, and Sarawak. The worst affected area mainly happened in Kelantar [2].

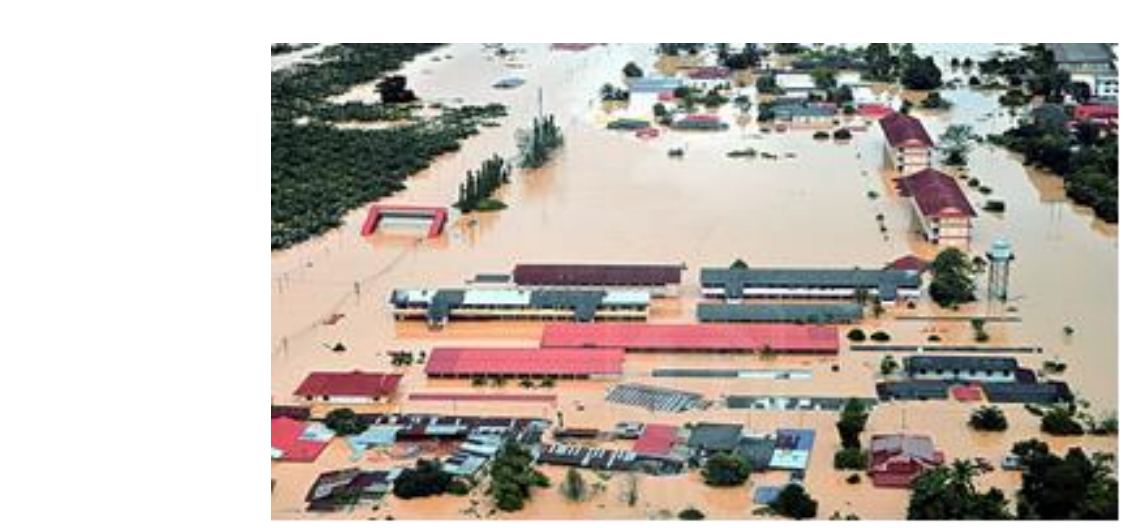

Figure 1. Recent Flood Disaster in Kota Bharu [3]

In Malaysia, according to Malaysian Drainage and Irrigation Department flood has been classified into two categories which are flash flood and monsoon floods [4]. From the hydrological perspectives, flash flood took only few hours to last while the monsoon flood can last for about one month. Malaysia is among the countries that seriously 
vulnerable to the flood due to high rainfall rates accumulates throughout the years especially during the monsoon periods [4].

Rain-gauges is a well-known tools capable to provide the most accurate means of measuring point rainfall, they require consistent maintenance, and their disposition density governs the accuracy with which catchment rainfall can be measured. Rainfall event analyses could be very important and significant by understanding the trend of the rainfall and the effect towards the country [5]. Precipitation analyses have been made throughout all over the world based on specific rain gauges data or climatological data [6].

A study in a tropical region i.e. Italy Silvano et al. [7] proposed a method for detecting extreme rainfall event for heavy precipitation event which known as Generalized Extreme Values (GEV). By using this model, Silvano et al. used a set of data for 30 years. The same procedure are used by Crisci et al. [8] to understand the estimation of the heavy rain. While Pandey [9] did the analysis about the extreme point rainfall event for Gorakhpur, India by analyzing the rain event for the past 50 years. Most of the model have been tested against data collected in long duration. However in this paper, analysis will be conducted at 5 different station for 17 hours 30 minutes during Malaysian worst flood event in December 2014.

The particulars of the data collection from the rain gauge for rainfall rate are briefly explained in Section 2. Afterwards, the analyses of the rain gauge data is discussed in Section 3. In Section 4, result of the analyses for the raingauge data is being discussed. Finally, Section 5 draws some conclusion and future works for flood estimation techniques.

\section{Data Collection}

In Malaysia, the tipping bucket type of painfall recorder is used as it is a digital recordings which give the ainfall rate data instantly to the user. Tipping bucket recorder has a bucket structure that collect the rainfall and once the rainfall exceeds a certain recorded value, the load of the rainfall in the bucket causes the bucket to tip. Each time the buckets tips, the time is recorded. As result a series of tips is recorded, the total amount of rain that occurred can be computed and recorded hence the tipping rate gives the intensity value of alinfall [5]. Figure 2 shows the tipping bucket used by the Malaysian Drainage and Irigation (DID). While Figure 3 shows the rain gauge location at five different station at Kota Bharu, Kelantan, Malaysia. Table 1 tabulate the location (latitude and longitude) of the five stations.

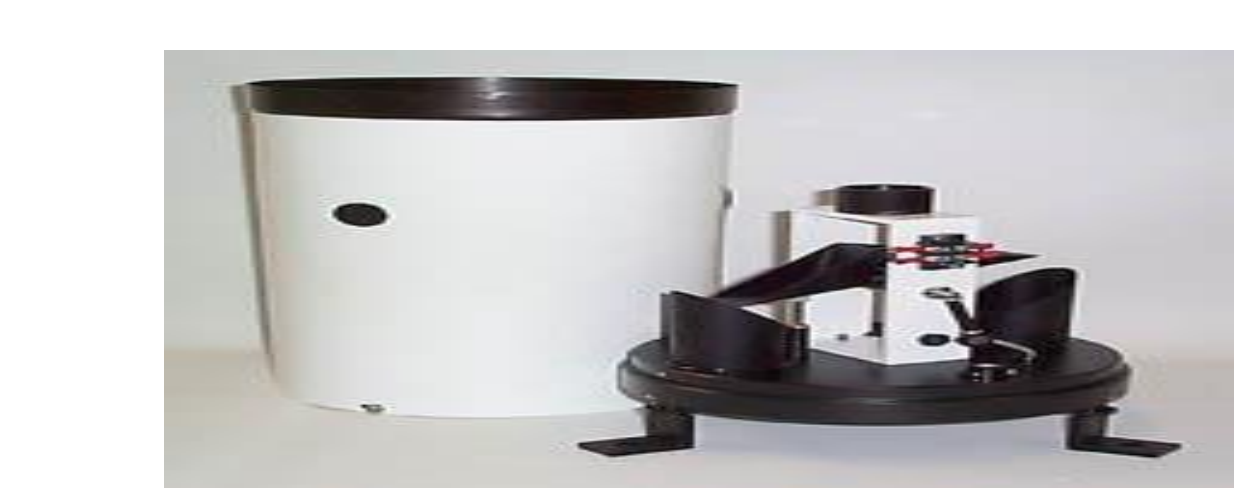

Figure 2. Tipping Bucket Rain Gauge [5] 


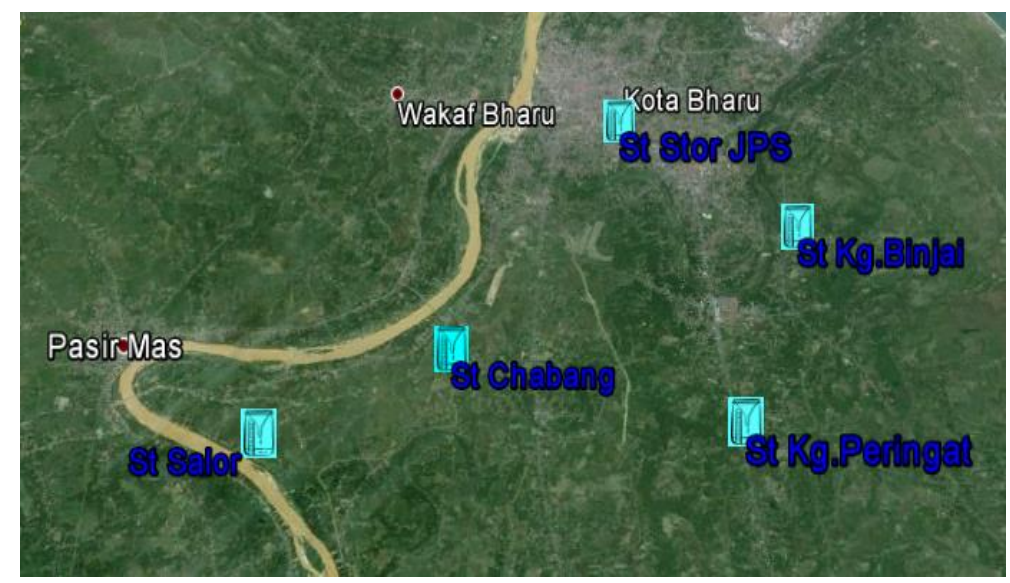

Figure 3. Location of the Rain Gauges

Table 1. Rain Gauge Details

\begin{tabular}{|c|c|c|c|}
\hline Station No. & Rain Gauge Name & Lat ${ }^{\circ} \gamma^{\prime}$ & Lon $\left.^{\circ}\right]^{\prime}$ \\
\hline 6021060 & Salor & $05^{\circ} 57^{\prime} 50^{\prime \prime}$ & $102^{\circ} 18^{\prime} 15^{\prime \prime}$ \\
\hline 6022062 & Chabang Tiga & $06^{\circ} 02^{\prime} 25^{\prime \prime}$ & $102^{\circ} 13^{\prime} 10^{\prime \prime}$ \\
\hline 6023001 & Kg.Binjar & $06^{\circ} 04^{\prime} 30^{\prime \prime}$ & $102^{\circ} 18^{\prime} 05^{\prime \prime}$ \\
\hline 6122064 & StorJPS & $06^{\circ} 06^{\prime} 30^{\prime \prime}$ & $102^{\circ} 15^{\prime} 25^{\prime \prime}$ \\
\hline 6022001 & KgPeringat & $06^{\circ} 01^{\prime} 15^{\prime \prime}$ & $102^{\circ} 17^{\prime} 15^{\prime \prime}$ \\
\hline
\end{tabular}

14 days of rainfall rate data before, during and after the flood tragedy were analysed. The peak event was between 13/12/2014-26/12/2014. There are 4032 of sample from the rain gauge data for every five minutes that had been analyze. The rain gauge generates total amount 5800 minutes of rainy time with five minute of integration time, from which 51 rain events were classified by considering at least 30 minutes a dry period time between an event and the following event. The accessibility of the recorded data for the whole 14 days period are $100 \%$ for whole 14 days. From the rain gauge data, we able to identify that the rain oceurred every day for the duration of 14 days. Table 2 displays the total number of rain engentoccurs at Kota Bharu.

Table 2. Rain Profile at Kota Bharu during 13/12/2014-26/12/2014

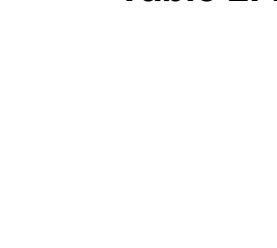

\begin{tabular}{|c|c|c|}
\hline Day & Date & No of Events \\
\hline 1 & $13 / 12 / 2014$ & 1 \\
2 & $14 / 12 / 2014$ & 5 \\
3 & $15 / 12 / 2014$ & 2 \\
4 & $16 / 12 / 2014$ & 8 \\
5 & $17 / 12 / 2014$ & 2 \\
6 & $18 / 12 / 2014$ & 6 \\
7 & $19 / 12 / 2014$ & 4 \\
8 & $20 / 12 / 2014$ & 4 \\
9 & $21 / 12 / 2014$ & 6 \\
10 & $22 / 12 / 2014$ & 3 \\
11 & $23 / 12 / 2014$ & 3 \\
12 & $24 / 12 / 2014$ & 3 \\
13 & $25 / 12 / 2014$ & 3 \\
14 & $26 / 12 / 2014$ & 1 \\
\hline & \multicolumn{2}{|c}{} \\
Total & \multicolumn{2}{|c}{} \\
\hline
\end{tabular}


Among this 51 rain events profile, the longest rain event had taken place on 17 December which lasted for 17 hours and 30 minutes. In order to categorize the heaviest rain among the entire rain event, the value of rain amount $(\mathrm{mm})$ in the rain gauge data must first converted into rainfall rate ( $\mathrm{mm} /$ hour). The highest value is $121.2 \mathrm{~mm} /$ hour at 20:45:00. According to the analyses at Salor Station, the longest rain event took place from 14.30 on 17 December 2014 last until 8.00 the next day. This time interval act as the reference for the other four stations. Data from the remaining four rain gauge stations are being analyses during the same time interval to see the trend of the rainfall. Figure 4(a) 4 (e) illustrated the rain events at the 5 rain gauge stations.

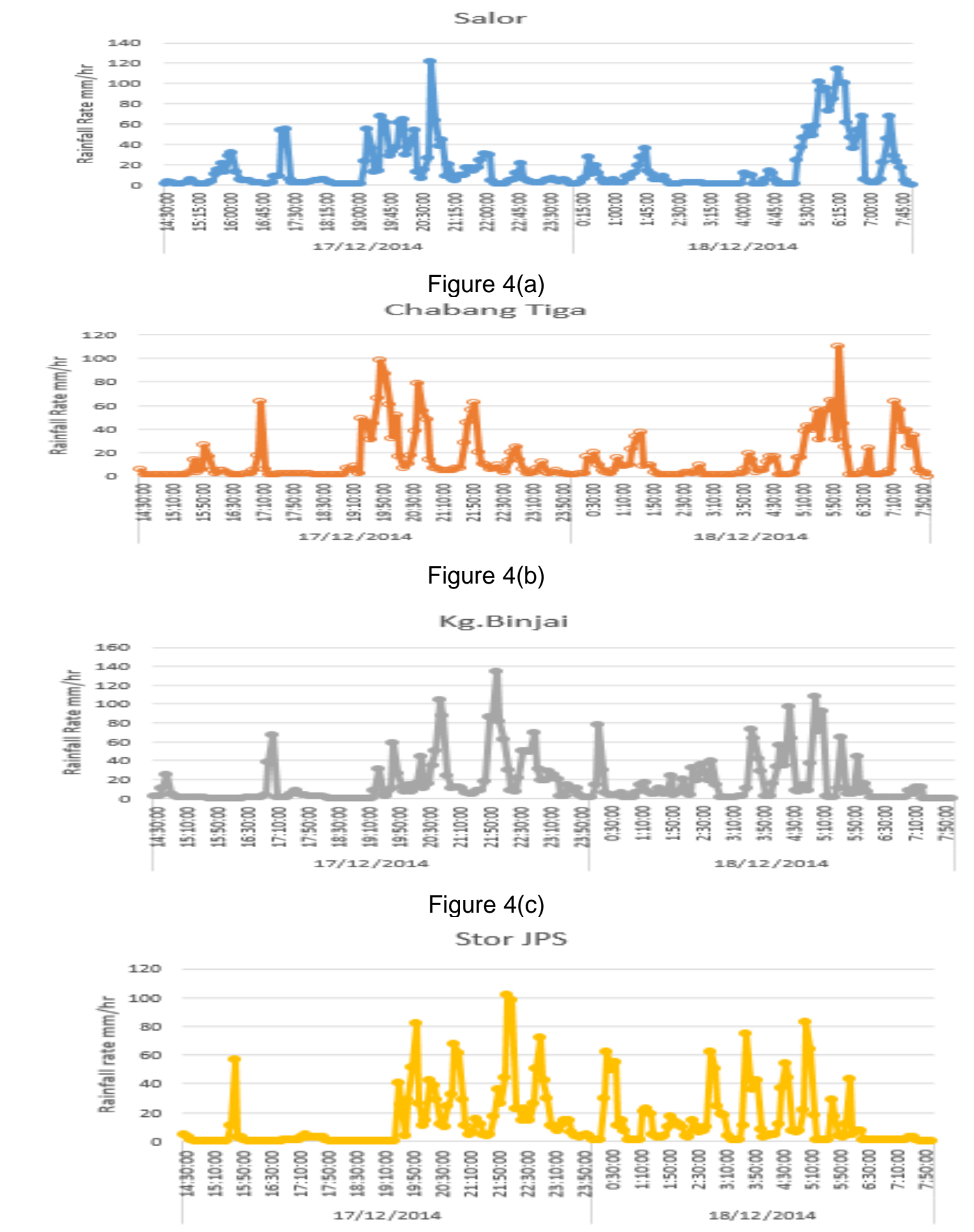

Figure 4(d) 


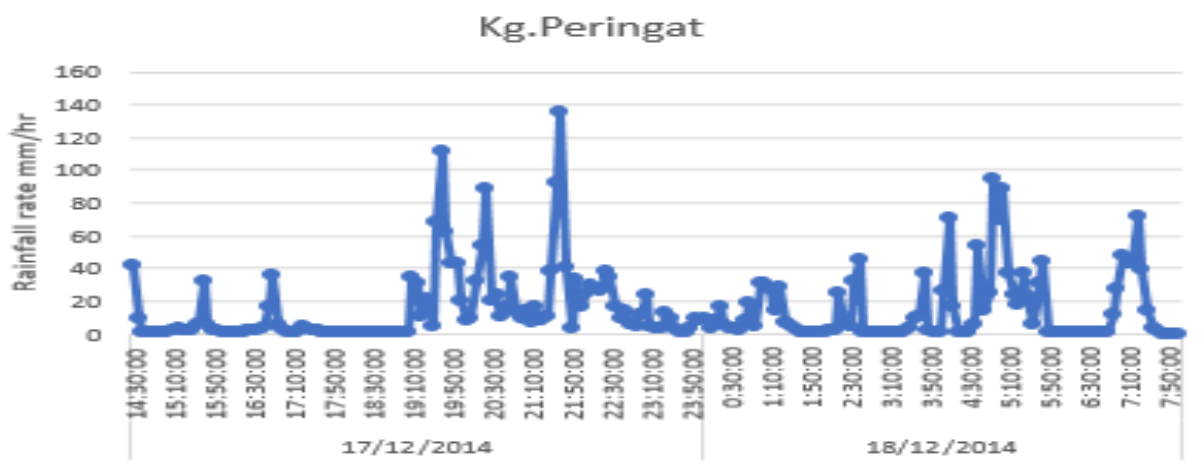

Figure 4 (e)

Figure 4(a)-4(e). Rain Event Profile for Each Stations

\section{Results}

Rainfall profile with the minimum value, maximum value, total, average data, and the $\mathrm{R}$ squared value for each event based on the graph above were recorded for each station and tabulated in the Table 2 .

Table 2. Rain Protile Information

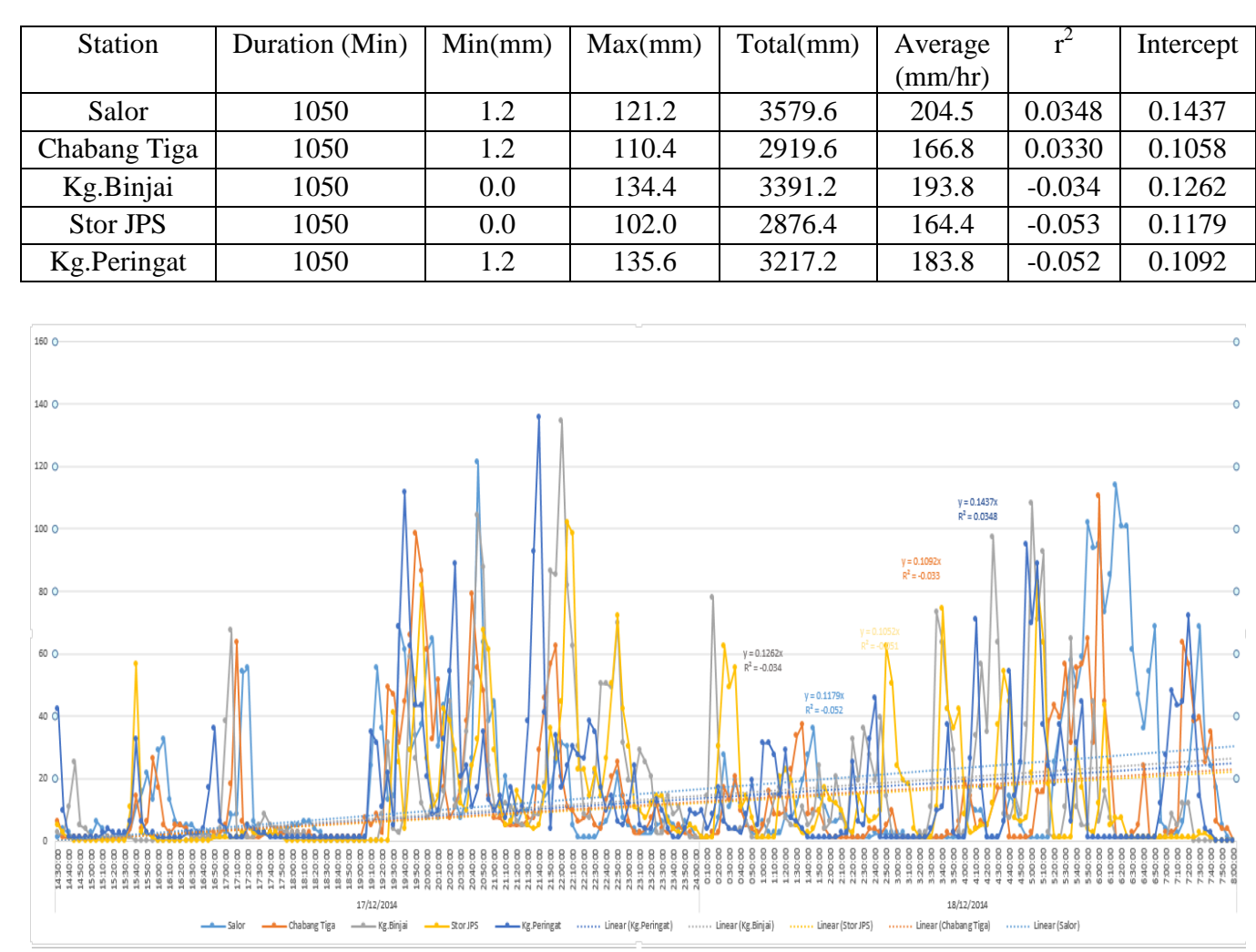

Figure 5. Comparison of Rain Event Profile of Five Different Stations

The graph of rain event profile in Figure 5 above were inspecting the period of the heavy rain from the rain gauge data corresponding to 17 hours and 30 minutes rainfall event during 17 December 2014 where the worst flood event occurred. Figure 5 also report the trend of the rainfall for five difference rain gauge stations. As appears from the graph, the trends seem similar to each other. In order to justify the trend, we calculate the 
slope for each station based on the highest reading for each graph. Figure 6 illustrates the slope at the highest rainfall rate for each station. Table 3 details the information of the slope for the highest rainfall rate value at each station. The relation of the increasing rainfall rate with time is expressed in the equation 1 .

$$
\mathrm{y}=\mathrm{mx}+\mathrm{c}
$$

Where $\mathrm{y}$ is the rainfall rate and $\mathrm{x}$ is the time. The slope, $\mathrm{m}$ shows the rate of change of the rainfall proportional to time.

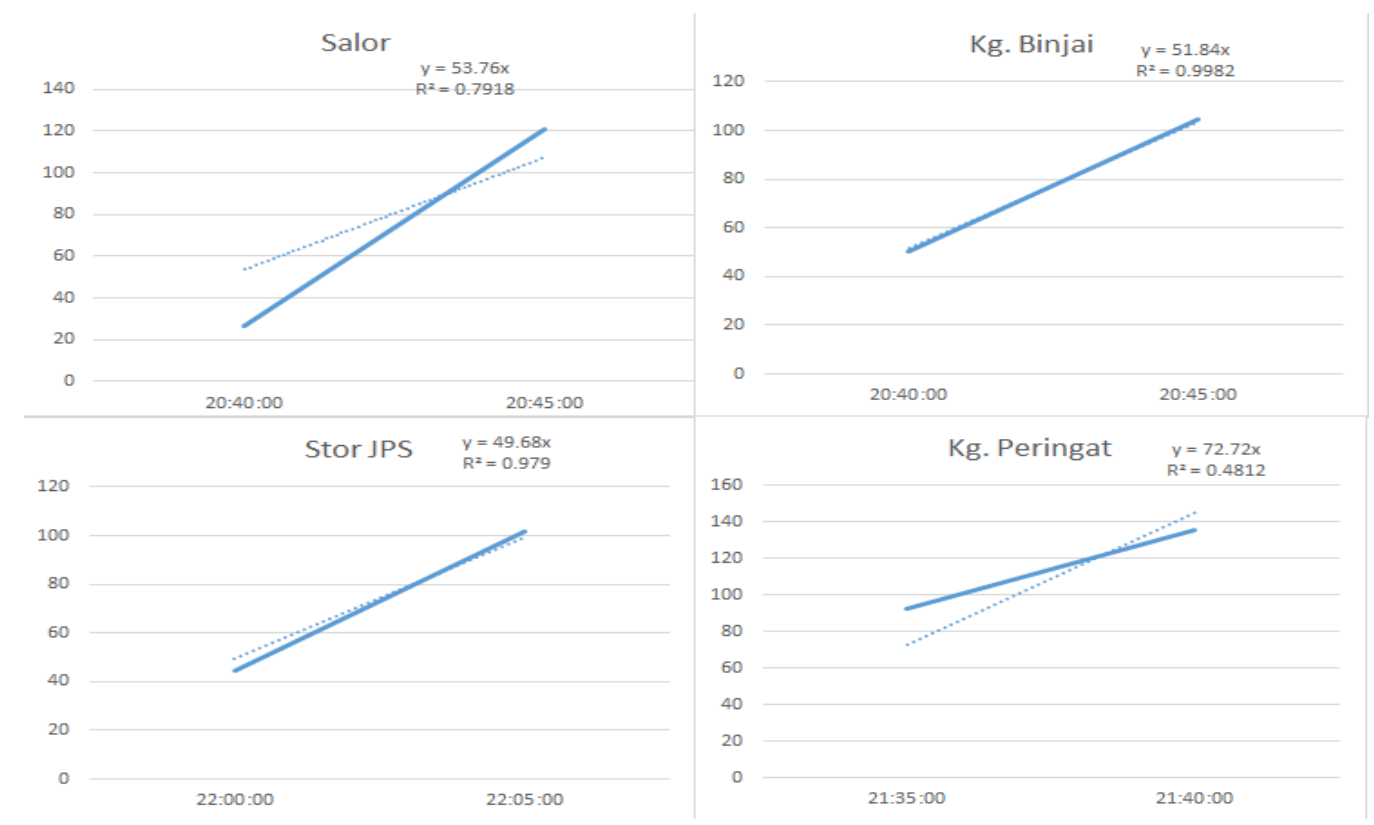

Figure 6. Slope for 4 Rain Gauge Stations

Table 3. Results for Slope Analysis

\begin{tabular}{|c|l|c|c|c|c|}
\hline Station & Start time & End time & Duration (Min) & $\mathrm{r}^{2}$ & Rainfall rate (y) and time relation $(\mathrm{x})$ \\
\hline Salor & $20: 40: 00$ & $20: 45: 00$ & 5 & 0.7918 & $\mathrm{y}=53.76 \mathrm{x}$ \\
\hline Chabang Tiga & $19: 45: 00$ & $19: 50: 00$ & 5 & 0.5698 & $\mathrm{y}=52.56 \mathrm{x}$ \\
\hline Kg.Binjai & $20: 40: 00$ & $20: 45: 00$ & 5 & 0.9982 & $\mathrm{y}=51.84 \mathrm{x}$ \\
\hline Stor JPS & $22: 00 ; 00$ & $22: 05: 00$ & 5 & 0.9760 & $\mathrm{y}=49.68 \mathrm{x}$ \\
\hline Kg.Peringat & $21: 35: 00$ & $21: 40: 00$ & 5 & 0.4812 & $\mathrm{y}=72.72 \mathrm{x}$ \\
\hline
\end{tabular}

The accunulated values of rainfall rate based on the rain gauge data is represented in the Figure 7. All five rain gauge stations displaying the same growth of rainfall rate durng the flood event. The average of total accumulated rainfall in 17 hours and 30 minutes at Kota Bharu is $3196.8 \mathrm{~mm}$. According to [10] monsoon rains are normally happen for a long duration of rainfall with irregular heavy burst and the rain intensity can occasionally exceed certain value as mention it was several hundred $\mathrm{mm}$ in one day duration. It is also important that the amount of more than $60 \mathrm{~mm} / \mathrm{hr}$ is considered heavy rain, while in this observation the average of rainfall rate occurred is $182.67 \mathrm{~mm} / \mathrm{hr}$. 


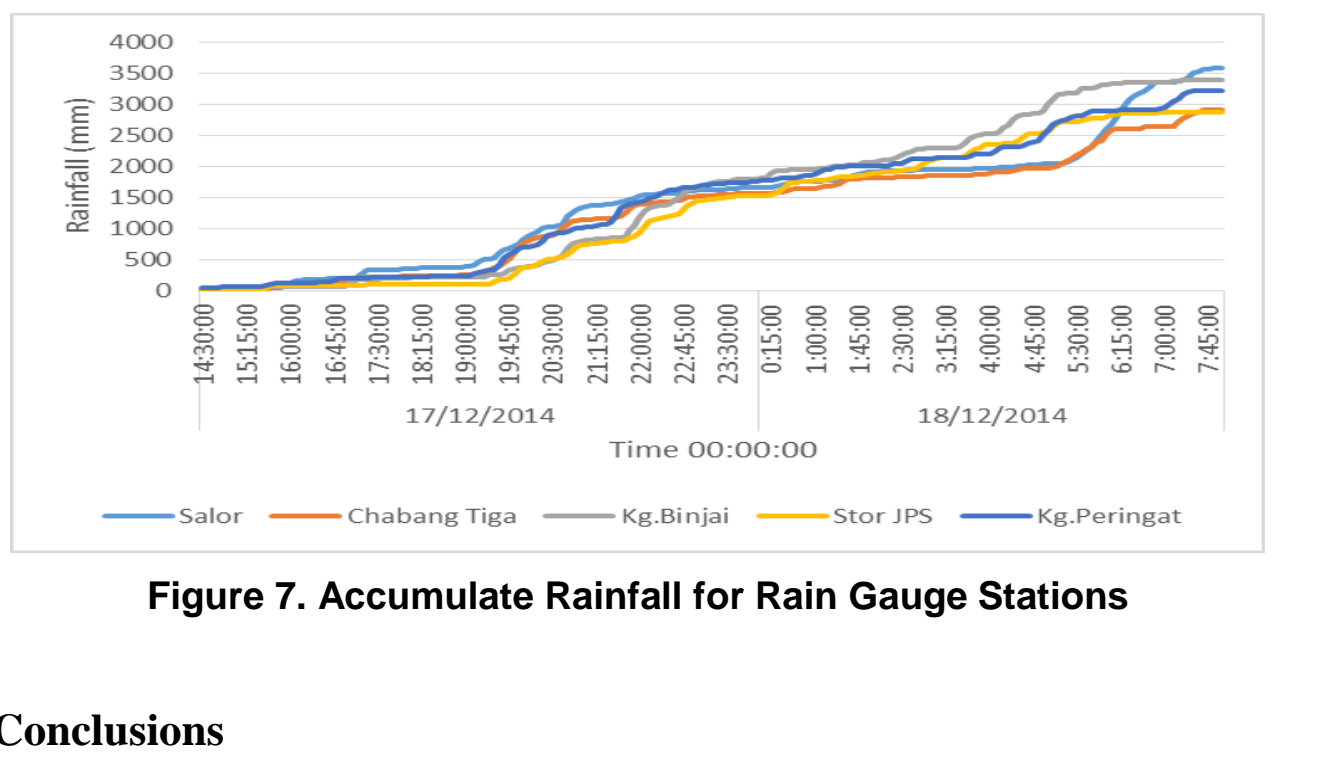

The analyses observed in this paper allows the estimation of the rainfall rate using rain gauge data. These information based on the rain gauge data for 5 stations located at Kota Bharu. In this paper, the researcher fixated on the rain gauge data during Malaysia worst flood in year 2014. According to our obserration a very extreme rain up to $182.67 \mathrm{~mm} / \mathrm{hr}$ has occurred during the flood disaster and affect the country comprise loss of human life, damage to assets, destruction of crops, damaged of iffrastructure facilities and worsening of health condition causes to wateporne infections. Our consequent target basically is to derive a coefficient for an algorithm or prediction technique that capable to predict flood disasters. As the result, anywhere after this if we noticed the similar behaviour of the rainfall and the cloud charaeteristics it will create an alarm system.

\section{Acknowledgments}

The researcher recognize the Research Management Centre of the International Islamic University Malaysia (IUUM) and Malaysian Ministry of Education for the financial assistance. The reported research outcome is part of the deliverables for the research funded under IIUM' Research University Initiatives. This research is being sponsored under FundamentaT Research Grant Scheme (FRGS) Research Project by Malaysian Ministry of Education.

\section{References}

[11 "International Federation of Red Cross and Red Crescent Societies", World disaster report. Oxford: Oxford University Press; (1998)

[2] "Worst floods in Kelantan, confirms NSC (2015-, Jan 5)", Retrieved fromwww.themalaymailonline.com/malaysia/article/worst-floods-in-kelantan.

[3] Posted on Wednesday, January $6 @$ 18:07:00 MYT by Siti Nurazlina Jamaludin retrieved from http://www.utusan.com.my/berita/nahas-bencana/banjir-satukan-pas-dan-umno-muhyiddin-1.45128.

[4] C. G. Collier, "Flash flood forecasting: What are the limits of predictability", Quarterly Journal of the Royal Meteorological Society Q. J. R. Meteorology. Soc., vol. 133, (2007), pp. 3-23.

[5] "DID Manual", -Hydrology and Water Resources, Department of Irrigation and Drainage, Government of Malaysia, Kuala Lumpur, vol. 4, (2009).

[6] F. T. Tangang, L. Juneng, E. Salimun, P. N. Vinayachandran, Y. K. Seng, C. J. C. Reason and T. Yasunari, "On the roles of the northeast cold surge, the Borneo vortex, the Madden-Julian Oscillation, and the Indian Ocean Dipole during the extreme 2006/2007 flood in southern Peninsular Malaysia”, Geophysical Research Letters, vol. 35, no. 14, (2008).

[7] S. Bertoldo, C. Lucianaz and M. Allegretti, "Extreme Rainfall Event Analysis Using Rain Gauges in a Variety of Geographical Situations", Atmospheric and Climate Sciences, vol. 5, (2015), pp. 82-9.

[8] A. Crisci, B. Gozzini, F. Meneguzzo, S. Pagliara and G. Maracchi, "Extreme rainfall in a changing climate: regional analysis and hydrological implications in Tuscany, Hydrol", Process, Published online 
in Wiley InterScience (www.interscience.wiley.com). DOI: 10.1002/hyp.1061, vol. 16, (2002), pp. 1261-1274.

[9] K. C. Pandey, "Extreme Point Rainfall Events Analysis of Gorakhpur under Climate Change Scenario", Journal Climatol Weather Forecasting 2:108. doi: 10.4172/2332-2594.1000107, (2014).

[10] “Kelantan", http://infobanjir2.water.gov.my/rainfall_page.cfm?state=KEL. InfoBanjir. Retrieved 201602-03.

\section{Authors}
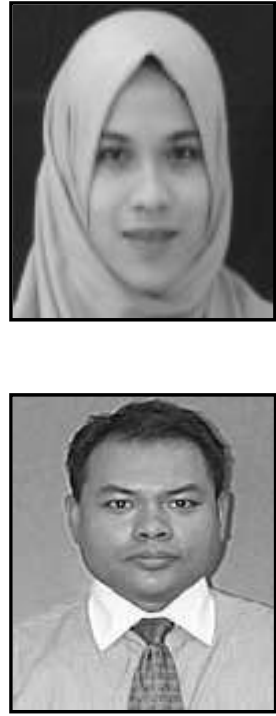

Atikah Balqis Basri, graduated in 2014 B. Eng. in Communication from the International Islamic University Malaysia (IIUM). She is currently a research officer whilst pursuing her MSc studies at the Electrical and Computer Engineering Department, IIUM. Her research interests are in radar.

Ahmad Fadzil Ismail, eurrently a lecturer at Department of Electrical and Computer Engineering Faculty of Engineering, International Islamic University Malaysia (IIUM). He completed his bachelor degree studies in Electrical Engineering at Gannon University, Pennsylvania, USA with Cum Laude Latin honors. He holds MSc and PhD from University of Essex, UK and University of Bath, UK, respectively. His research interests include development of active and passive target tracking algorithms, radio frequency and wireless systems and mitcrowave and milimetrewave technology. He is registered with Board of Engineering Malaysia as a Professional Engineer and alsoa senior member of IEEE.

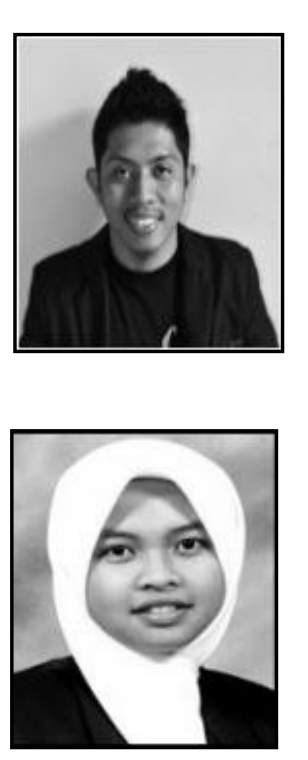

M. H. Khatrolanuar, was born in Johor Bahru, Malaysia, in 1989. He recelved the B.Eng. degree from the International Islamic University of Malaysia (IIUM), Gombak, in 2013 in conmunication engineering. He is currently pursuing the M.S. degree with the Department of Electrical and Computer Engineering, IIUM studies in radar and radiometry research. His research interests include millimeter and microwave propagation studies. He is also a member of IEEE.

K. Badron, obtained her BEng (2006), Msc (2011) and Ph.D (2016) from International Islamic University Malaysia (IIUM). She is currently one of the faculty members of Faculty of Engineering, IIUM and recently commenced her research areas in Radar and Radiometry research, quantifying propagation effects on microwave and millimetre wave links. Khairayu is a member of IEEE, IEM,BEM and MTSFB. She has published and co-authored more than 15 papers in International Journals as well as Conferences on subjects relating to rain attenuation in the tropical regions. 

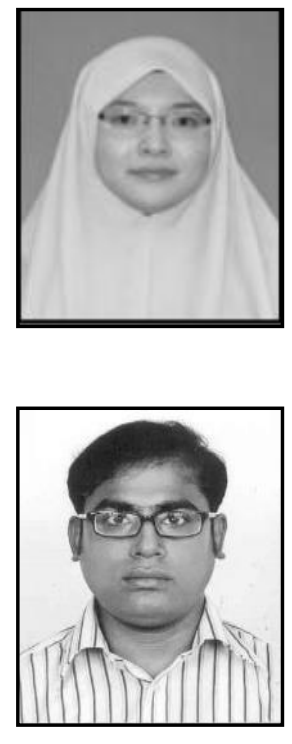

N. H. M. Sobli, a fellow lecturer at the Dept of Electrical and Computer Engineering, Faculty of Engineering, International Islamic University Malaysia. She received BEng and MSc from International Islamic University Malaysia specializing in communications engineering. She is currently pursuing her Ph.D candidacy. Her research interests are wireless communication, radar radiometry and rainfall rate modeling.

Mohammad Kamrul Hasan, is currently a $\mathrm{PhD}$ candidate in Communication Engineering at the department of Electrical and Computer Engineering in International Islamic University, Malaysia. $\mathrm{He}$ achieved his received his Masters in Communication Engineering from International Islamic University, Malaysia in 2012. His current research interests include OFDMA, Interference, Cognitive Network, Optimization, Smart Grid Computing, and Data Communication and Networking. He published more than $\$ 0$ paper in international journals and conferences.

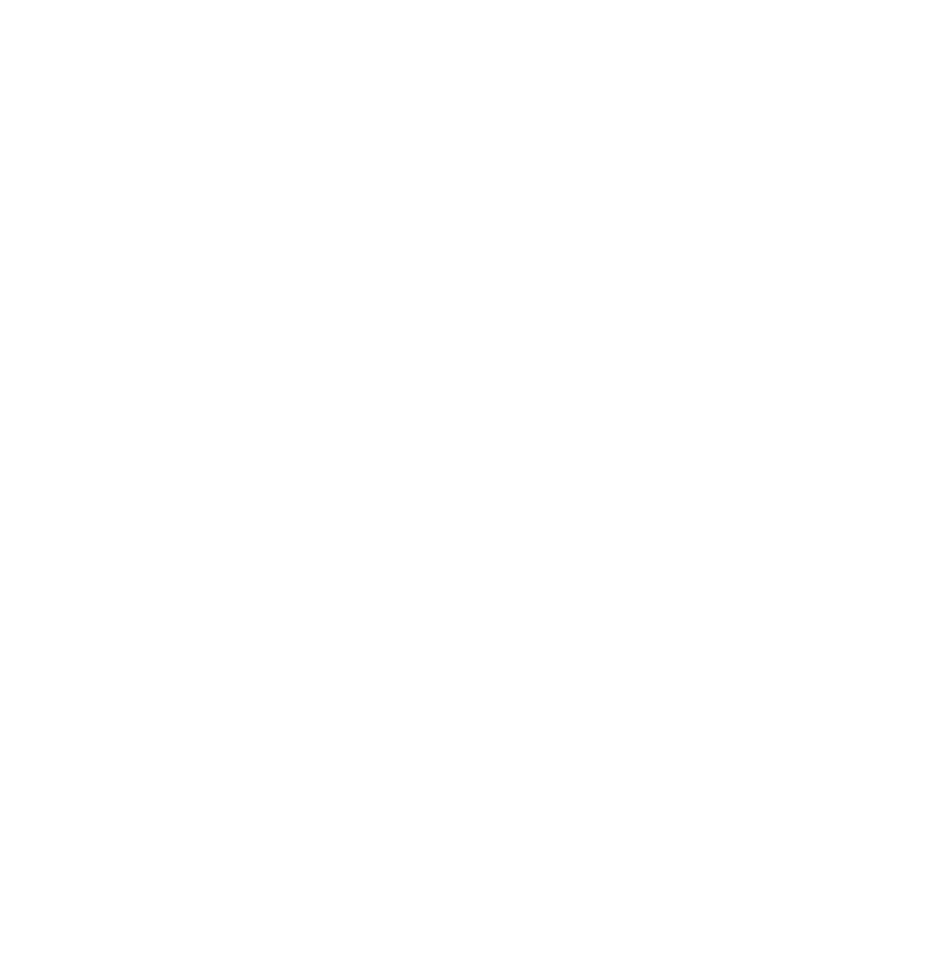


International Journal of Multimedia and Ubiquitous Engineering

Vol.11, No.8 (2016)

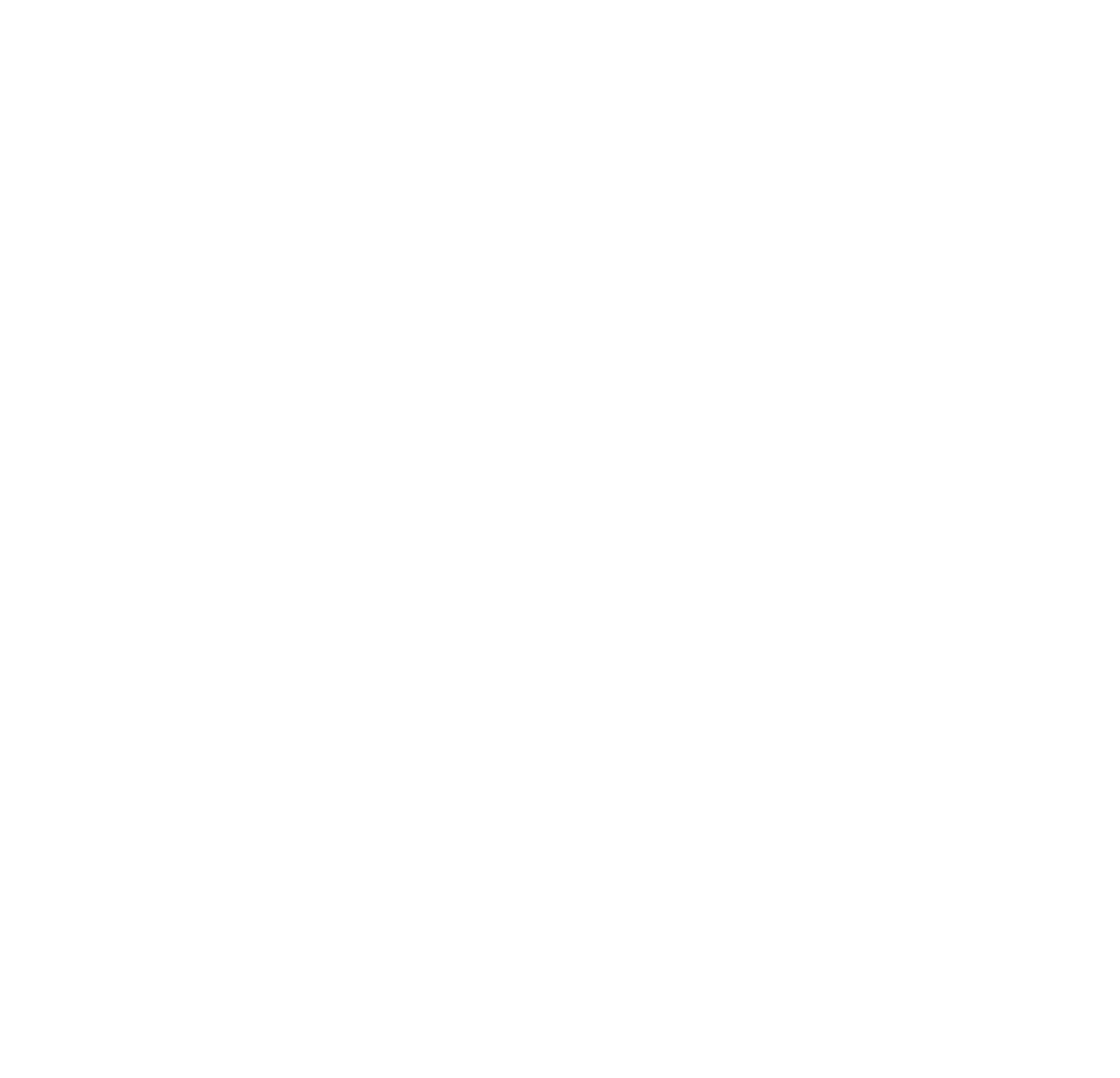

